\title{
A CRITICAL NOTE ON THE LATIN TRANSLATION OF ARISTOTLE'S DE ANIMA USED BY ZABARELLA IN HIS COMMENTARY ON THIS WORK
}

\author{
Jules Janssens \\ De Wulf-Mansion Centre, KU Leuven
}

In a recent book, S. Salatoswky indicated that Zabarella in his Commentary on De anima uses essentially Guillaume of Moerbeke's translation of Aristotle's text. This is not completely mistaken, but nevertheless is in need of qualification. ${ }^{1}$ Indeed, already a first, quick overlook shows the presence of important modifications on the terminological level. They exceed these cases where Zabarella, based on the Greek text, proposes himself a new translation. I will show that Zabarella, besides making personal interventions, paid also attention to M. Sophonias' translation, which had been published in the Venice 1562 edition of Averroes' Great Commentary, as well as to the Arabic-Latin translation as given in the textus of the latter. ${ }^{2}$ This seriously indicates that Zabarella used that edition, or, otherwise, its 1574 reprint. This comes as no surprise, insofar as Zabarella, in spite of elements of harsh criticism against Averroes, clearly admired the latter. ${ }^{3}$ In addition, Zabarella has taken advantage from the translation of Aristotle's text that Gentianus Hervetus made together with that of Philoponus' Commentary on the De anima ${ }^{4}$ In what follows I will not offer an exhaustive survey of all the differences between Moerbeke's translation and the textus quoted by Zabarella. Based only on the eight first texts of each of the three books of Zabarella's commentary, I will try to highlight in an exemplary way the significance of these modifications and, at the same time, to fix as precisely as possible their exact source. ${ }^{5}$

1 S. Salatowsky, De anima. Die Rezeption der aristotelischen Psychologie im 16. und 17. Jahrhundert (Bochumer Studien zur Philosophie, 43). Amsterdam: Benjamin, 2006, p. 139.

2 See Aristotelis De anima libri tres, cum Averrois commentariis et antiqua translatione ... Hic accessit eorundem liborum Aristotelis nova translatione ... Michaele Sophiano interprete. Venetiis, Apud Iuntas, 1562 (reprinted in 1574). It is worthwhile to note that in this latter edition one finds also quoted Moerbeke's translation (called: 'antiqua translatio'), and that Sophonias' translation was also printed in D. Thomae Aquinatis In libros De anima expositio. Cum triplici textus translatione, antiqua, Argyropyli et Michaelis Sophiani ... . Venetiis, Apud Iuntas, 1565. Note that Sophonias explicitly states that he did not feel free to make an entirely new translation, but that he was not free to depart from the vocabulary of the vulgate version since this vocabulary was essential to Aristotelian and Averroist philosophy, see F. E. Cranz, « Editions of the Latin Aristotle Accompanied by the Commentaries of Averroes », in E.P. Mahoney (ed), Philosophy and Humanism : Renaissance Essays in Honor of Paul Kristeller, Brill, Leiden, 1976, pp. 116-128, especially pp. 127-128.

3 Regarding Zabarella's complex attitude toward Averroes, see my forthcoming "La position de Zabarella dans son Commentaire sur le De anima vis-à-vis d'Averroès" (to be published in the acts of the colloquium 'Les lumières de l'Orient médiéval aux racines de la Renaissance européenne', held at Paris, ENS, 2017). In this paper I argue that, contrary to what is generally admitted, Zabarella's commentary is in all likelihood not incomplete (or, if incomplete, then at most regarding book 3, textus 21-36).

4 See Aristotelis Stagiritae De anima libri tres, e Graeco, quae proxima fieri potuti, in Latinam traduce, Gentiano Herveto Aurelio interprete. ITEM, In eosdem libros Ioannis Grammatici Philoponi Commentarius ab eodem versus. Lugduni, 1544.

5 These textus cover respectively Aristotle's De anima, I, 1, 402a1-b9; II, 1, 412a3-b17 and III, 4, 429 a10-b10. 
When one looks at he first textus of the first book: "Bonorum et honorabilium notitiam opinantes magis autem alteram altera, aut secundum certitudinem, aut ex eo quod et meliorum et mirabiliorum est, propter utraque haec animae historiam rationabiliter utique in primis ponemus", one might have the impression that Zabarella, after all, simply reproduces Moerbeke's translation. ${ }^{6}$ Certainly, compared to the latter one finds one minor modification, i.e. the replacement of 'quidem' after 'meliorum' by 'et' this conjunction being placed of course before the latter word. ${ }^{7}$ But one could imagine that this was an already attested variant in the transmission of Moerbeke's translation. ${ }^{8}$ However, a much more significant modification appears in textus 2 , where the Greek verb ' $\sigma v \mu \beta \alpha \dot{\alpha} \lambda \lambda \varepsilon \sigma \theta \alpha \mathrm{l}$ ' (402a5) is no longer rendered by 'proficere', in accordance with Moerbeke, but by 'conferre', as given by Sophonias and Hervetus. ${ }^{9}$ In

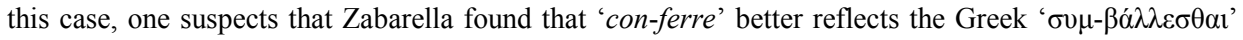
than 'pro-ficere' does. Later we will see a most telling example of his particular sensibility to the meaning of presuppositions in compound Greek words. In textus 3 one finds further evidence of Zabarella's occasional use of Sophonias' translation: 'Quaerimus' (instead of Moerbeke's 'Inquirimus') and 'alia (...) alia' (instead of 'aliae [...] aliae'). ${ }^{10}$ Moreover, one reads at the end: "(alia autem) communes et animalibus propter illam inesse" instead of Moerbeke's translation as given by Gauthier: "(aliae autem) propter ipsam communes et animalibus inesse". However, Zabarella' wording literally corresponds to the 'antiqua translatio', as present in the 1562 edition of Averroes' Great commentary, hence to one of the variants of Moerbeke's translation. ${ }^{11}$ Finally, special attention deserves the use of 'contemplari' for translating the Greek verb ' $\theta \varepsilon \omega \rho \tilde{\eta} \sigma \alpha$ ' (402a7). One looks in vain for this precise term in Moerbeke, who uses 'considerare', or in Sophonias, who opts for 'spectare'. Based on Zabarella's commentary, one has the impression that he derived this term from Thomas Aquinas' commentary, but I looked in vain for it in the Sentencia libri de anima, to which one would expect Zabarella is referring to. If Zabarella indeed had the latter work in mind, he clearly did not find the term 'contemplari' as such, but, at best, a hint to use it, insofar as according to Thomas we have a less certain knowledge of the higher and more noble things than of lower things. ${ }^{12}$ However, the very term 'contemplari' is present in Hervetus' translation of Aristotle's textus that precedes Philoponus' commentary. ${ }^{13}$ Hence, Hervetus' translation formed almost certainly Zabarella's direct source, all the more since the latter insists that Philoponus' explanation largely

6 See J. Zabarella, Commentarii Jac. Zabarellae Pativini In III. Aristot. Libros de Anima . Venetiis, 1606-1607 [reprint Minerva, Frankfurt 1966], fol. 1. The first edition of the work was published in 1605 (also at Venice, apud Franciscum Bolzettam). Let me note that in the edition of Zabarella's commentary, one finds always 'contextus' instead of 'textus' as far as the first book is concerned. However, in books 2 and 3 one finds only 'textus'. So, for the sake of ease I use that term also when discussing the fragments of book 1.

7 In absence of a critical edition of Moerbeke' translation in the series Aristoteles Latinos, we refer to that translation as edited by R.A. Gauthier in Sancti Thomae de Aquino Sentencia libri de anima ( Sancti Thomae de Aquino Opera omnia, 45,1). Rome, Commissio Leonina, 1984. For the present fragment (as well as the following ones up to 7), see Ibid., p. 3.

8 For the complex transmission of that translation, see the long introduction of Gauthier to the edition of Thomas' Sentencia libri de anima, see previous note.

9 See Zabarella, In III. Aristot. Libros de Anima, f. 19; as to Sophonias' translation, see Aristotelis De anima libri tres, cum Averrois commentariis, f. 1vE, and with regard to Hervetus's, see Aristotelis Stagiritae De anima libri tres, Liber primus, f. 2 (left) (in absence of any sign of pagination in the edition).

10 Zabarella, In III. Aristot. Libros de Anima, f. 26; for Sophonias: Aristotelis De anima libri tres, cum Averrois commentariis, f. 2rA. Let me add that the wording "Quaerimus' is also used by Hervetus, see Aristotelis Stagiritae De anima libri tres, Liber primus, f. 2 (right).

11 Aristotelis De anima libri tres, cum Averrois commentariis, f. 2rA.

12 It is well-known that for Thomas God and the Higher Beings are rather object of 'contemplation' than of 'knowledge'.

13 Aristotelis Stagiritae De anima libri tres, Liber primus, f. 2 (right). It might be the case that the addition of 'quidem' after the first occurrence of 'alia' was also inspired by Hervetus's translation. 
corresponds with Thomas' understanding of the involved notion. ${ }^{14}$ In textus 4 , several minor interventions are based on, or, at least, inspired by Sophonias: the addition of 'et' before 'multis aliis'; the use of ' $e a$ ' instead of 'eam' after 'dico autem', and the replacement of 'ea quae (quid est)' by 'ipsius [Sophonias: ipsum] (quid est) ${ }^{\prime} .{ }^{15}$ As to the inversion of 'communis quaestio' into 'quaestio communis', it is not only present in Sophonias, but also in a large part of the transmission of Moerbeke's translation. ${ }^{16}$ Of particular interest are however the very opening words of the textus: "Omniquaque autem et omnino". In Moerbeke's translation, we read: "Omnino autem et penitus", while Sophonias has: "Verum usque-

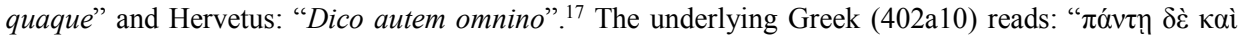
$\pi \alpha ́ v \tau \omega \varsigma$ ". One has the impression that Zabarella was not satisfied by one single of these translations and therefore proposed its own translation, trying to do as maximal as possible justice to both the content and the morphological structure of both Greek terms. In textus 5, further traces of Sophonias' influence show up: 'de ipso' instead of 'de eo', 'difficilior fit' instead of 'difficilius est' and the addition of 'autem' before 'manifestum'. ${ }^{18}$ Further, one detects in one case a direct influence of Hervetus' translation: 'adhuc' instead of 'amplius'.$^{19}$ It has to be observed moreover that Zabarella has replaced the infinitive 'negotiari' by the substantive 'negotiatio' (while adding before it 'ipsa'), maybe inspired by Sophonias, who, however, uses another term, i.e. 'perscrutatio'. Finally, he offers a personal translation of the conjunction

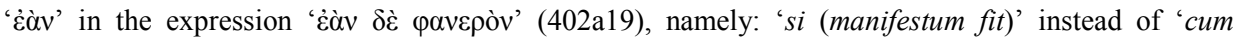
[Sophonias: ubi; Hervetus: quando] manifestum fuerit [Hervetus: fuit]'. Herein one may detect anew Zabarella's great attention to the so-called 'small' words of the Greek language, as propositions, conjunctions, etc. In textus 6, one finds in the quotation of the textus the following formulation: "an qualitas, aut quantitas aut etiam quoddam aliud", but, when repeated later in the commentary one reads: "an qualitas, an quantitas an etiam aliud". ${ }^{20}$ The former formulation is more in line with Moerbeke's "aut qualitas, aut quantitas aut etiam quoddam aliud", whereas the latter, as far as the formulation of the involved multiple alternative is concerned, corresponds more to Sophonias' wording, i.e., "an quale, aut quantum an etiam aliud". ${ }^{21}$ This offers a strong indication that Zabarella was always looking at both translations, and, while taking Moerbeke's translation as basis, made revisions, a large part of which is inspired by Sophonias's. The omission of 'aliquid' before 'parvum' at the end is once more in line with Sophonias' wording. ${ }^{22}$ But the replacement of 'endeleichia (entelechia)' by 'actus' is almost certainly due to a personal initiative of Zabarella, for which he found however support in the commentaries of

14 In the Latin translation of Philoponus' commentary, one reads: "Dicimus enim contemplari quidpiam, quando ad id simpliciter aggredimur. Nosse autem ipsum, quando ea etiam qua ei insunt edidicimus" (see ibid., f. 2 [right]), an affirmation that indeed has much in common with Thomas's explanation as presented by Zabarella.

15 Zabarella, In III. Aristot. Libros de Anima, f. 31; Sophonias: Aristotelis De anima libri tres, cum Averrois commentariis, f. $2 \mathrm{vD}$.

16 See Sancti Thomae de Aquino Sentencia libri de anima, p. 3, n. 12; the same variant is also given in the 'translatio antiqua' accompanying Averroes's Great Commentary, see Aristotelis De anima libri tres, cum Averrois commentariis, f. $2 \mathrm{rC}$.

17 For Sophonias and Hervetus, see Aristotelis De anima libri tres, cum Averrois commentariis, f. 2vD, respectively Aristotelis Stagiritae De anima libri tres, Liber primus, f. 3(left).

18 Zabarella, In III. Aristot. Libros de Anima, f. 34; for Sophonias: Aristotelis De anima libri tres, cum Averrois commentariis, f. $3 \mathrm{rA}$.

19 Aristotelis Stagiritae De anima libri tres, Liber primus, f. 4 (right).

20 Zabarella, In III. Aristot. Libros de Anima, f. 38; for the quotation in the commentary, see ibid., f. 39E.

21 Aristotelis De anima libri tres, cum Averrois commentariis, f. 3rC.

22 It is corresponds moreover to Hervetus' translation, see Aristotelis Stagiritae De anima libri tres, Liber primus, f. 5 (left), as well as to the Arabic-Latin translation accompanying Averroes' Great Commentary, see Aristotelis De anima libri tres, cum Averrois commentariis, f. 3vD. 
Averroes and Philoponus. ${ }^{23}$ Textus 7 reveals the existence of only two minor modifications: the replacement twice of 'aut' by 'an', and the omission of 'quidem' after 'nunc', which both correspond to Sophonias' wording (although in the latter case, Zabarella maintains Moerbeke's reading 'nunc', hence does not take over Sophonias' alternative translation 'iam', undoubtedly because he judged that the former better corresponds with the Greek võv [402b3]). In textus 8, one has anew a case of replacement of 'aut' by 'an', based on Sophonias. ${ }^{24}$ The replacement of 'aliquod' before 'commune' by 'quod' (or: 'quid') is in all likelihood taken from Hervetus' translation. ${ }^{25}$ As to the replacement of 'Deique' by 'Dei', albeit present in both Sophonias and Hervetus, was probably not inspired by them, but is simply a variant in the transmission of Moerbeke's translation, as shown by its presence in the 'antiqua translatio' of the 1562 edition of Averroes' Great Commentary. ${ }^{26}$ But special attention deserves the very beginning, where

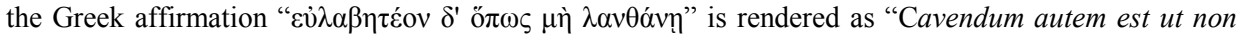
lateat" (becoming, when repeated in the commentary, "Cavendum est ne lateat"), whereas Moerbeke has: "Formidandum autem quatinus non lateat". Sophonias, on his turn, translates: "Caeterum cavendum est ne nos lateat", while Hervetus renders as follows: "Cavendum est autem ne nos lateat". Hence, Zabarella clearly prefers the translation "cavendum est ne", presented by Sophonias and Hervetus, for the Greek expression " $\varepsilon \dot{\jmath} \lambda \alpha \beta \eta \tau \dot{\varepsilon}$ ov ( $\delta$ ') ö $\pi \omega \zeta$ " ("one has to be careful to") over Moerbeke's translation. However, with Moerbeke and Hervetus, pace Sophonias, he opts for maintaining 'autem' — undoubtedly based on the presence of ' $\delta \dot{\varepsilon}$ ' in the Greek; and with Moerbeke alone he omits any reference to 'nos', since it is at best implicit in the Greek. One finds here a very good illustration of Zabarella's complex dealing with Moerbeke's translation.

Turning to book II, we find immediately in textus 1 confirmation of a personal intervention of Zabarella, when he reformulates Moerbeke's "Quae quidem (...), iterum autem tanquam...." into "Cum autem (...), iterum tanquam". ${ }^{27}$ One also finds a case that confirms the use of a variant in Moerbeke's tradition, as testified in the 'antiqua translatio' related to Averroes' Great Commentary, i.e. the addition of the verb 'sunt' after 'tradita'. ${ }^{28}$ Finally, the use of 'a principio' instead of 'ex principio' points to a direct influence of Hervetus' translation. ${ }^{29}$ As to textus 2 , we find a case where the beginning of the text as quoted before the commentary differs from its quotation a little later inside the commentary itself. In the present case, one seriously suspects a misprint in the textus, insofar as it affirms "Dicimus itaque unum quoddam genus eorum quae substantia", which is rather meaningless. In the commentary, on the contrary, Moerbeke's translation: "Dicimus itaque unum quoddam genus eorum quae sunt, substantiam",

23 Aristotelis De anima libri tres, cum Averrois commentariis, f. 3vD ("endelechia, scilicet in actu"), respectively Aristotelis Stagiritae De anima libri tres, Liber primus, f. 5 (right) ("vel entelechia quaedam seu quidam actus"). I think it might be worthwhile to note that already Jacques of Venice, in his translation of the present fragment, added to the Greek word 'E்v $\tau \varepsilon \lambda \dot{\varepsilon} \chi \varepsilon 1 \alpha$ ' 'idest perfectio vel actus', see the website Brepolis Latin Complete: Aristoteles Latinus Database (ALD) (Brepolis).

24 Zabarella, In III. Aristot. Libros de Anima, f. 47; for Sophonias: Aristotelis De anima libri tres, cum Averrois commentariis, f. 4rA.

25 For Hervetus, see Aristotelis Stagiritae De anima libri tres, Liber primus, f. 6 (left) (“quid aliud"). In the quotation of the textus preceding Zabarella's commentary, one reads in the Renaissance edition 'quod', but in the repetition of the text in the commentary itself (f. 49A) one finds 'quid' instead of 'quod'.

26 See Aristotelis De anima libri tres, cum Averrois commentariis, f. 4rA.

27 Zabarella, In III. Aristot. Libros de Anima, f. 105. Regarding Moerbeke's translation, see Sancti Thomae de Aquino Sentencia libri de anima, p. 67 (Moerbeke's translation as given on this page corresponds to Zabarella's textus 1-7; for textus 8, see ibid., p. 74).

28 See Aristotelis De anima libri tres, cum Averrois commentariis, f. 48vD.

29 Aristotelis Stagiritae De anima libri tres, Liber secundus, f. 3 (right); as to Sophonias, he uses as well the preposition ' $a(b)$ ', but he modifies 'principio' into 'initio', see Aristotelis De anima libri tres, cum Averrois commentariis, f. $48 \mathrm{vD}$. 
is verbatim quoted. ${ }^{30}$ Moreover, one finds a variant of Moerbeke's translation as given in the 'antiqua translatio' that is present in in Averroes' Great Commentary, namely 'iam dicitur' instead of 'dicitur iam' ${ }^{31}$ In perfect conformity with what we saw in textus 6 of b. I, Zabarella replaces also in the present textus 'endelechia' by 'actus'. Furthermore we find a replacement of 'quae' after 'tertium' by 'quod' in conformity with both Sophonias and Hervetus. ${ }^{32}$ With Hervetus, and as well the Arabic-Latin translation present in Averroes' Great Commentary, Zabarella opts for translating the Greek word 'Ẽ̃ioos' (412a10) by 'forma' instead of by 'species', as Moerbeke and Sophonias had done. ${ }^{33}$ Finally, and most striking, is his use of 'speculari' instead of 'considerare' (Moerbeke) or 'contemplari' (Sophonias/Hervetus) for the Greek infinitive ' $\theta \varepsilon \omega \rho \varepsilon \tilde{v} v$ ' (412a11). However, the Arabic-Latin translation uses the very same term. ${ }^{34}$ In textus 3, the three occurrences in Moerbeke's translation of 'physicus' (physica, physicorum, physicum) are systematically replaced by the wording 'naturalis' (naturalia, naturalium, naturale) in line with

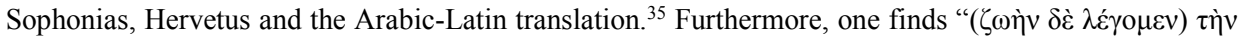

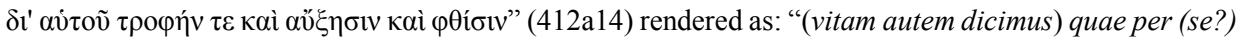
ipsum sit alitionem, augmentationem et diminutionem" instead of "(vitam autem dicimus) id quod per seipsum alimentum et augmentum et decrementum". ${ }^{36}$ The wording as given in Zabarella is almost identical with Hervetus's: "(vitam autem dicimus) quae per seipsum sit nutritionem, auctionem et diminutionem". ${ }^{37}$ Zabarella's use of 'augmentationem' might result form a combined use of Moerbeke (augmen-) and Hervetus (-tionem). However, the use of (the unusual) 'alitionem', instead of Hervetus' 'nutritionem', is surprising, and I see no immediate reason why Zabarella in this case has proposed an entirely new translation. ${ }^{38}$ No misprint seems to have happened in the printing of the textus, since the very same term 'alitio(nem)' is present when the sentence is repeated in the commentary. ${ }^{39}$ Finally, the replacement of 'sicut' at the end of the fragment by ' $u t$ ' is almost certainly based on Sophonias' and Hervetus' translations. ${ }^{40}$

From here on, I will no longer mention all the variants present in the different textus, but limit myself to the most significant cases. In textus 5, one finds the Greek infinitive ' $\theta \varepsilon \omega \rho \varepsilon i v$ ' (412a23 and 25) twice

30 For the textus, see Zabarella, In III. Aristot. Libros de Anima, f. 108C-D and for the quoted sentence in the commentary, ibid., 108E.

31 See Aristotelis De anima libri tres, cum Averrois commentariis, f. 48vD.

32 See Averroes' Great Commentary, see Aristotelis De anima libri tres, cum Averrois commentariis, f. 49rA, respectively Aristotelis Stagiritae De anima libri tres, Liber secundus, f. 3 (right).

33 Regarding Hervetus' translation, see Aristotelis Stagiritae De anima libri tres, Liber secundus, f. 3 (right); as to the Arabic-Latin translation, see Averroes' Great Commentary, see Aristotelis De anima libri tres,

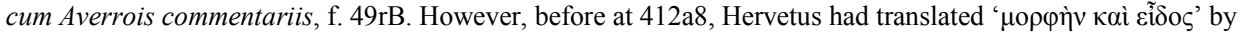
'figura et forma', whereas Zabarella, following Moerbeke, maintains the translation 'formam et speciem'.

34 See Aristotelis De anima libri tres, cum Averrois commentariis, f. 49rB.

35 For the textus, see Zabarella, In III. Aristot. Libros de Anima, f. 115; regarding Sophonias' translation as well as the Arabo-Latin translation, see Aristotelis De anima libri tres, cum Averrois commentariis, f. 49vDE. As to Hervetus' translation, see Aristotelis Stagiritae De anima libri tres, Liber secundus, f. 4 (left). The same replacement appears also later in e.g., textus 4, 6 and 8, and therefore is in all likelihood systematic.

36 It seems likely that 'se' has accidentally fallen out in the textus because Zabarella, in his commentary, when repeating the sentence, states: "vitam autem dicimus eam quae per se sit alitionem", see Zabarella, In III. Aristot. Libros de Anima, f. 118, and, moreover, Hervetus' translation, which clearly influenced the present wording, has also 'seipsum' (for the precise reference, see following note).

37 See Aristotelis Stagiritae De anima libri tres, Liber secundus, f. 4 (left).

38 The term is absent of most dictionaries of classical and medieval Latin; however, it is recorded in M. Fuchs, O. Weijers and M. Gumbert (eds), Lexicon Latinitatis Nederlandicae Medii Aevi. Leiden, Brill, 19702005 , vol. I, p. 184, A 232, as synonymous with 'nutritio'.

39 See above, n. 35.

40 See Aristotelis De anima libri tres, cum Averrois commentariis, f. 49vE, respectively Aristotelis Stagiritae De anima libri tres, Liber secundus, f. 4 (left). 
rendered by 'speculatio', hence neither by 'considerare' (Moerbeke) nor 'contemplari' (Sophonias/ Hervetus). ${ }^{41}$ The rejection of this latter translation might look at first sight puzzling, especially in view of translation of the Greek verb $\theta \varepsilon \omega \rho \tilde{\eta} \sigma \alpha \mathrm{l}$ by 'contemplari' in textus 3 of book $1 .{ }^{42}$ But Sophonias probably is well aware that that in the present context, where the act of ' $\theta \varepsilon \omega \rho \varepsilon \tilde{v}$ ' is explicitly linked with the state of wakefulness, the term 'contemplari' is not really appropriate given that it, as we saw, properly refers to a higher, albeit less certain, type of knowledge. Certainly more difficult to explain is the translation "somnus autem habitui non exeunti in actu(m)" for the Greek affirmation: "ó $\delta$ ' vँ $\pi v o \varsigma \tau \tilde{\varphi}$ है $\chi \varepsilon t v$

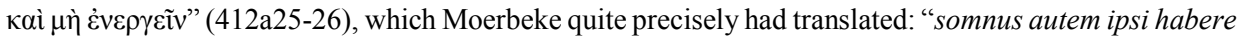
et non operari", a translation that Sophonias took over as such, and Hervetus only modified in a minor way by using 'cum eo quod est' instead of 'ipsi' ${ }^{43}$ I suspect an influence of the Arabic-Latin translation, which states: "somnus autem est similis dispositions rei, cum potest agere et non agit". ${ }^{44}$ However, Zabarella seems to have replaced the term 'dispositio' by the more technical term 'habitus', which, moreover, is etymologically linked with the verb 'habere'. If this reveals to be correct, he has in a similar way replaced the general 'agere' by the more technical 'exire in actum'. In the same way as 'physicus' (and its related forms) is replaced by 'naturalis' (and its related forms), as we have seen before, 'organum' (and its related forms) is replaced by 'instrumentum' (and its related forms), as is evidenced in both texts 6 and $8 .^{45}$ This replacement is based on the sole translation of Hervetus, since the three other ones (Moerbeke, Sophonias and the Arabic-Latin) all have 'organum' (and its related forms). The replacement of Moerbeke's 'fructiferi [-um]' (Sophonias: 'pulpae [-a]'; Arabic-Latin translation: vestes [fructibus]), which translates the Greek word ' $\pi \varepsilon \rho ı \alpha \rho \pi_{1}$ ov[-ov]' (412b2-3), by 'eius [id] quod circa fructum' is also inspired by Hervetus' translation: 'eius [id] quod fructum ambit', and it alone, even if it is not completely identical. In fact, by replacing Hervetus' verb 'ambit' by the preposition 'circa', Zabarella shows once more his particular attention to the preposition used in compound Greek words, as here e.g., ' $\pi \varepsilon \rho \mathrm{l}-\kappa \alpha \rho \pi i ́ \varsigma^{\prime}$ '. Another significant replacement is that of Moerbeke's 'dolobra [-ae]' (Greek: ' $\pi \dot{\varepsilon} \lambda \varepsilon \kappa \cup \varsigma[\pi \varepsilon \lambda \varepsilon \dot{\kappa \varepsilon 1]}$ ' (412b412b12-14) by 'securis [-i]' in textus 8, but now supported by all three other translations used by Zabarella, i.e. Sophonias, Hervetus and the Arabic-Latin translation. ${ }^{46}$

To conclude our examination, we will still mention a few cases related to the first eight textus of book

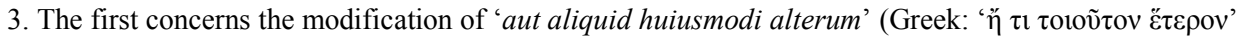
[429a14-15]) into 'aut aliquid aliud tale' at the end of textus $2 .{ }^{47}$ Zabarella takes the beginning 'aut

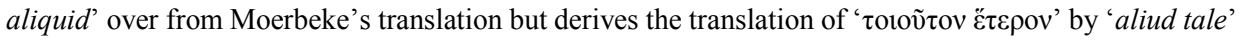

41 For the textus, see Zabarella, In III. Aristot. Libros de Anima, f. 129; regarding Sophonias' translation, see Aristotelis De anima libri tres, cum Averrois commentariis, f. 50vE, and as to Hervetus' translation, see Aristotelis Stagiritae De anima libri tres, Liber secundus, f. 5 (left).

42 See above, p. 266.

43 For the textus, see Zabarella, In III. Aristot. Libros de Anima, f. 131; Note that the addition of an 'm' to 'actu' almost imposes itself and find confirmation in the printed Venice edition of Zabarella's commentary of 1605 (see Iacobi Zabarellae Patavani In Tres Aristotelis Libros de Anima Commentarii. Nunc primum editi, cum indices rearm copiosissimo, liber secundus, f. 7r). For Sophonias and Hervetus, see Aristotelis De anima libri tres, cum Averrois commentariis, f. 50vE, respectively Aristotelis Stagiritae De anima libri tres, Liber secundus, f. 5 (left).

44 See Aristotelis De anima libri tres, cum Averrois commentariis, f. 49vE.

45 See Zabarella, In III. Aristot. Libros de Anima, f. 131 and f. 151.

46 With regard to Sophonias' translation, respectively the Arabic-Latin translation, see Aristotelis De anima libri tres, cum Averrois commentariis, f. $52 \mathrm{rC}$, respectively $52 \mathrm{vD}$; as to Hervetus' translation, see Aristotelis Stagiritae De anima libri tres, Liber secundus, f. 6 (right).

47 See Zabarella, In III. Aristot. Libros de Anima, f. 673. Regarding Moerbeke's translation, see Sancti Thomae de Aquino Sentencia libri de anima, p. 201 (Moerbeke's translation as given on this page corresponds to Zabarella's textus 1-7; for textus 8, see ibid., p. 208). 
from Hervetus, who translates: 'vel aliud tale' ${ }^{48}$ In the same way, Hervetus, but now together with the Arabic-Latin translation, has clearly inspired him to modify inside textus 3 Moerbeke's '(susceptivum

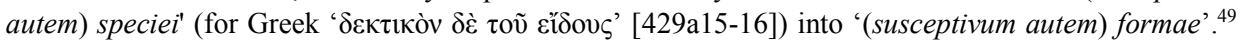

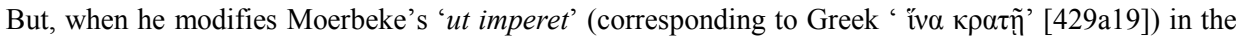
next, fourth textus, into '(ut?) dominetur', he, this time, is indebted to the sole Sophonias, who states: ' $u t$ dominetor five superet ${ }^{50}$ Of utmost significance, however, is to see that Zabarella, in the same textus, renders the Greek ' $\pi \alpha \rho \varepsilon \mu \varphi \alpha$ ivó $\mu \varepsilon v o v$ ' (429a20) by 'iuxta apparens' instead of 'intus apparens'. In this respect it is worthwhile to quote extensively the following remark that he makes in his commentary: "Est autem notandum vis verborum Aristotelis, quod enim legimus iuxta apparens, solet a multis dici: intus apparens, et id recte, quia Graecum participium, quod hic habemus, utrumque significat, nam participium Graecum $\pi \alpha \rho \varepsilon \mu \varphi \alpha \imath{ }^{\prime} \mu \varepsilon v o v$ est compositum ex $\pi \alpha \rho \grave{\alpha}$, quod est iuxta, et $\dot{\varepsilon} v$, quod est in sive intus, et paivó $\mu \varepsilon v o v$, quod est apparens". It is obvious that Zabarella would have preferred to render both prepositions involved in the Greek word into Latin, but since there is no room for such articulation in the framework of the Latin language, he has given preference to translate explicitly the first particle, and this against an important part of the tradition as he himself observes. Nevertheless, he admits that the latter found a direct support for its translation in the very structure of the Greek participle itself. Some scholars might find this far-fetched, but in my view it reveals a will to combine as much as possible philological and philosophical skills, and this, of course, according to the prevailing views of that time. In textus 5, Zabarella, in accordance with Sophonias and Hervetus, prefers 'existimat' over 'intelligit' as translation

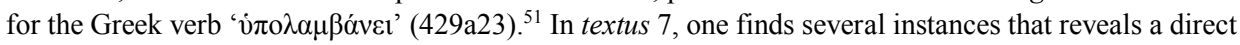
influence of Hervetus' and/or Sophonias' translation on Zabarella: 'ex sensoriis' instead of 'ex sensitivi'

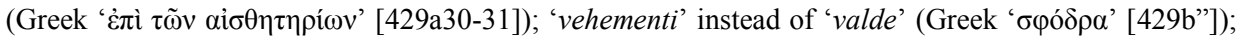
'cum (=Moerbeke, Sophonias: 'ubi' and Hervetus: 'quando') aliquid intellexerit' instead of 'cum

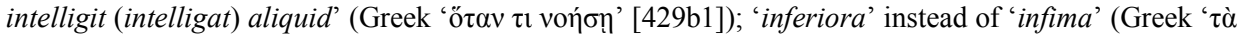

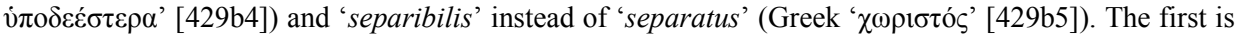
mentioned only by Hervetus, and the fourth by Sophonias, while the three others are present in both. ${ }^{52}$ The first case illustrates well Zabarella's great sensitivity to maintain a maximum correspondence between the translation and the original Greek text: a plural word in the Greek has to be rendered, if possible, by a plural word in Latin. On the other hand, the last case shows that he pays serious attention to the philosophical content: to translate ' $\chi \omega \rho \iota \sigma \tau$ ós' by 'separabilis', not by 'separatus', leaves clearly more room for affirming a possibly close link between intellect and body. Finally, a very interesting case

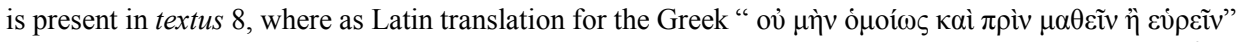
(429b8-9) Zabarella proposes: "non tamen similiter ut et erat antequam addisceret aut inveniret". ${ }^{53}$ In Moerbeke's translation, it is formulated as follows: "non tamen similiter et ante addiscere aut invenire". As to Sophonias, he renders it: "non tamen aeque ac priusquam didicisset aut invenisset", while Hervetus

48 For this latter, see Aristotelis Stagiritae De anima libri tres, Liber tertius, f. 26 (right).

49 See Zabarella, In III. Aristot. Libros de Anima, f. 683. For Hervetus' translation, see Aristotelis Stagiritae De anima libri tres, Liber tertius, f. 26 (right), where one reads: 'susceptivum autem esse speciei'; as to the Arabic-Latin translation, see Aristotelis De anima libri tres, cum Averrois commentariis, f. 137rA (reading, however, 'sed recipit formam').

50 See Zabarella, In III. Aristot. Libros de Anima, f. 692; for Sophonias, see Aristotelis De anima libri tres, cum Averrois commentariis, f. 137vD.

51 See Zabarella, In III. Aristot. Libros de Anima, f. 739; for Sophonias, see Aristotelis De anima libri tres, cum Averrois commentariis, f. 137vD, and for Hervetus, see see Aristotelis Stagiritae De anima libri tres, Liber tertius, f. 27 (left)

52 See Zabarella, In III. Aristot. Libros de Anima, f. 758; for Hervetus, see Aristotelis Stagiritae De anima libri tres, Liber tertius, f. 27 (right) and for Sophonias, see Aristotelis De anima libri tres, cum Averrois commentariis, f. $154 \mathrm{vE}$, and

53 See Zabarella, In III. Aristot. Libros de Anima, f. 774. 
has: "non autem similiter ac priusquam didicerit vel invenerit" ${ }^{54}$ Finally, the Latin-Ara-bic translation states: "sed non eodem modo quo ante erat antequam scivit aut invenit". ${ }^{55}$ The very first three words, i.e. 'non tamen similiter', are identical with Moerbeke's translation. The addition of 'ut' after 'similiter' seems to be proper to Zabarella, but might have been inspired by the 'quo' related to 'eodem modo' in the Arabic-Latin translation. ${ }^{56}$ With Moerbeke, Zabarella hereafter maintains the conjunction ' $e t$ ', which directly corresponds to the Greek ' $K \alpha i$ '. However, the formula 'erat antequam' that immediately follows this conjunction is clearly not based on Moerbeke's translation. In fact, it is beyond any reasonable doubt that in the present case Zabarella makes the formulation of the Arabic-Latin translation his. Finally, he maintains Moerbeke's vocabulary, i.e. 'addiscere aut invenire' for the final part, but since he introduced the conjunction 'antequam' he replaces the infinitive by the third person singular of the subjunctive imperfect. For this latter, he might have been somehow inspired by Sophonias, who, however, had used the subjunctive pluperfect, albeit after 'priusquam', which Zabarellla has replaced by (the more or less synonymous) 'antequam' based on the Arabic-latin translation, as indicated above. Once more, one detects that Moerbeke's translation is indeed important for Zabarella, but that he nevertheless modifies its very wording, mainly inspired by other Latin translations that he had at his disposal.

I hope that from what precedes it is evident that Zabarella modifies on several occasions and in several ways Moerbeke's translation, and therefore that the translation he presents has perhaps to be best qualified as a revised version of Moerbeke's, similar to, albeit not identical with the way that Moerbeke's translation itself was a revision of the old translation of of Jacques of Venice.

54 See Aristotelis De anima libri tres, cum Averrois commentariis, f. $155 \mathrm{rC}$, respectively Aristotelis Stagiritae De anima libri tres, Liber tertius, f. 27 (right)

55 See Aristotelis De anima libri tres, cum Averrois commentariis, f. 155vD.

56 Zabarella, who obviously prefers Moerbeke's (and Hervetus') translation 'simpliciter' over that of 'eodem modo' for 'ó $\mu$ oí $\omega \varsigma^{\prime}$ ', clearly cannot but use ' $u \mathrm{t}$ ' instead of 'quo'. 